CARPATHIAN JOURNAL OF FOOD SCIENCE AND TECHNOLOGY

journal homepage: http://chimie-biologie.ubm.ro/carpathian_journal/index.html

\title{
EVALUATION OF POSTHARVEST BEHAVIOR OF COCONUT (Cocos nucifera L.)
}

\author{
Lucas Aguirre Juan Carlos ${ }^{1,2 *}$, Tobón Castrillón Cynthia ${ }^{1}$, Cortés Rodríguez Misael ${ }^{1}$ \\ ${ }^{1}$ Universidad Nacional de Colombia - Sede Medellín. Calle 59 A N 63-20, Medellín, Colombia. \\ ${ }^{2}$ Universidad del Quindío - Carrera 15 Calle 12 N, Armenia - Colombia. \\ *jclucasa@unal.edu.co
}

https://doi.org/10.34302/crpifst/2019.11.3.7

Article history:

Received:

21 March 2018

Accepted:

28 July 2019

Keywords:

Coconut water;

Coconut pulp;

Physical-chemical;

Physical properties;

Useful life.

\section{ABSTRACT}

Coconut is a Tropical fruit of interest for Colombia; one part of its production is used at industrial level; nonetheless, there is little diversification of products with added value and lack of availing of coconut water, the husk, and peel. The aim of this research was to evaluate the behavior of the physical and physical-chemical properties of coconut pulp $(\mathrm{CP})$ and its coconut water $(\mathrm{CW})$ during storage at $25^{\circ} \mathrm{C}$, to determine the adequate time for use as raw material for its transformation, using a completely random design (CRD) via analysis of variance (ANOVA) and Tukey tests, with $5 \%$ significance level. Where the independent variable were the control times at 15, 22, 29, 36, 43, and 50 days after harvest, at the rate of 3 coconuts/lot for each control time. Among the response variables we determined the percentage distribution of the $\mathrm{CP}, \mathrm{CW}$, and inner shell (endocarp), as well as properties of $\mathrm{Xw}, \mathrm{pH}$, soluble solids, acidity, $\mathrm{a}_{\mathrm{w}}$, color $\left(\mathrm{L}^{*}, \mathrm{a}^{*}, \mathrm{~b}^{*}\right)$, viscosity, and texture. Results showed general $\mathrm{CP}$ and $\mathrm{CW}$ deterioration after de 36 days of storage, mainly due to increased acidity, fermentation odors, loss of Xw, lipid oxidation (LO), and $\mathrm{CP}$ softening and discoloration, among others.

\section{Introduction}

Coconut represents a raw material of great interest in the Colombian Caribbean and Pacific. Its production was of $114,773 \mathrm{t}$ in 2013, with the departments of Nariño, Córdoba, and Cauca the principal producers: 33.7, 26.1, and $15.1 \%$, respectively (Agronet, 2013). At agro-industrial level, the kernel is used mainly to produce coconut milk (CM) and dehydrated coconut. In addition, coconut oil is used in the cosmetics sector (Debmandal and Mandal, 2011; Seow and Gwee, 1997). Compositionally, CP has been evaluated with Xw: $41.7 \pm 0.5 \%$, fat: $40.2 \pm 1.2 \%$, proteins: $4.1 \pm 0.3 \%$, sugar: $5.6 \pm 0.2 \%$, and raw fiber: $3.5 \pm 0.1 \%$; while dehydrated $\mathrm{CP}$ present fat content values: $65.5 \pm 2.0 \%$, protein: $6.8 \pm 0.4 \%$, sugar: $6.5 \pm 0.3 \%$, raw fiber: $9.2 \pm 0.2 \%$, and carbohydrates: $6.0 \pm 0.2 \%$.
(Yalegama et al., 2013). Other authors have evaluated the quality of Macapuno coconut in mature state during 42 days of storage, to simulate conditions in retail markets, finding that at $30{ }^{\circ} \mathrm{C}$ the fruit undergoes a high respiration rate between 40 and $60 \mathrm{mg} \mathrm{CO}_{2} \mathrm{~kg}^{-}$ ${ }^{1} \mathrm{~h}^{-1}$ with 3-day maximum storage time. At 2 and $5{ }^{\circ} \mathrm{C}$ the respiration rate diminishes $(4$ and $20 \mathrm{mg}$ $\mathrm{CO}_{2} \mathrm{~kg}^{-1} \mathrm{~h}^{-1}$, respectively) with a low rate of ethylene production $\left(0.6\right.$ and $0.8 \mathrm{Lkg}^{-1} \mathrm{~h}^{-1}$, respectively), permitting a storage life up to six weeks (Luengwilai et al., (2014). This weight loss limitation is also accompanied by darkening of the nucleus and of the degree of fat oxidation (Luengwilai et al., 2014). The aim of this research was to evaluate the behavior of the physical and physical-chemical properties of $\mathrm{CP}$ 
and $\mathrm{CW}$, Enano Malayo variety (manila), during storage at $25{ }^{\circ} \mathrm{C}$ to determine the adequate time for its processing as raw material for its transformation.

\section{Materials and methods}

\subsection{Materials}

The fruit yield was determined as percentage ratios of the $\mathrm{CP}, \mathrm{CW}$, and the inner shell (endocarp). The $\mathrm{CP}$ and $\mathrm{CW}$ characterization was performed in terms of humidity $(\mathrm{Xw})$ : AOCW method 930.15/90; water activity $\left(\mathrm{a}_{\mathrm{w}}\right)$ : spray point hygrometer (Aqualab series 3TE, Decagon, Devices, Pullman, WA, USA) (Cortés-Rodríguez et al., 2007); ${ }^{\circ}$ Brix: AOCW method 932.12/90; LO: the proportional mix $(\mathrm{CP}+\mathrm{CW})$ was evaluated by using the spectrophotometric method (Hornero-Méndez et al., 2001) and determining the extractable oil through the method described by Bae \& Lee, (2008) modified; viscosity of the CW $(\mu)$ : rheometer (Brookfield DV-III Ultra (Brookfield Engineering Laboratories, Inc., USA) a $25^{\circ} \mathrm{C}$, ULA spindle and velocity at $250 \mathrm{rpm}$ (Mirhosseini et al., 2008); CP texture: determined the $\mathrm{CP}$ average firmness $\left(\mathrm{F}_{\mathrm{CP}}\right)$ through penetration tests in a texture analyzer (TA-TA-XT2i, Stable Microsystems Ltd., United Kingdom), 25-kgf load cell, stainless steel probe $(\phi=5 \mathrm{~mm})$, rate of penetration: 1.0 $\mathrm{mm} \mathrm{s}^{-1}$ and penetration distance of $3 \mathrm{~mm}$ (Prieto et al., 2011); acidity index (IA): AOCW method 942.05/90, expressed as malic acid for CW and as lauric acid for $\mathrm{CP}$; $\mathrm{pH}$ : AOCW method 981.12/90; color: coordinates of the CIELAB $\left(\mathrm{L}^{*}:\right.$ Luminosity, $\mathrm{a}^{*}$ : red-green chromaticity, $\mathrm{b}^{*}$ : yellow-blue chromaticity), X-Rite spectrophotometer, $\mathrm{D}_{65}$ illuminant, and $10^{\circ}$ observer (Cortés, 2004). In addition, bromatological characterization was carried out: fat (AOCW method 920.39/90), proteins (AOCW method 955.04/90), total dietary fiber (AOCW method 985.29/90), and ashes (AOCW method 942.05/90). Calcium quantification was performed via atomic absorption spectrophotometry, according to NTC 5151 of 2003. A completely random design (CRD) was used to evaluate the results, with analysis of variance (ANOVA) and Tukey tests, with 5\% significance level. The independent variable were the control times at 15, 22, 29, 36, 43, and 50 days after harvest, at the rate of 3 coconuts/lot for each control time and the response variables for $\mathrm{CP}$ and $\mathrm{CW}$ were: $\mathrm{Xw}, \mathrm{a}_{\mathrm{w}}, \mathrm{pH}$, color $\left(\mathrm{L}, \mathrm{a}^{*}\right.$, $\left.\mathrm{b}^{*}\right)$, IP, soluble solids. Texture and acidity index were also determined for CP. For CW: density and percentage of acidity and percentage distribution of CP, CW, and peel.

\subsubsection{Samples}

The study used coconuts (Cocos nucifera L.) of the Enano Malayo (Manila), Tumaco, Colombia varieties, with an age from bloom to harvest of 12 months. Three lots were evaluated (three samples/lot) up to 50 days after harvest (dah).

\section{Results and discussions}

The bromatological composition of $\mathrm{CP}$ at 15 dah (date received in the collection center) was the following: $\mathrm{Xw}$ : $53.5 \pm 6.4 \%$, protein $3.3 \pm 0.3 \%$, dietary fiber $12.9 \pm 2.5 \%$, fat $19.9 \pm 3.0 \%$, ashes $1.1 \pm 0.3 \%$; additionally, calcium contents for $\mathrm{CP}$ and $\mathrm{CW}$ were statistically similar, $146.3 \pm 41.3$ and $108.0 \pm 16.5$ $\mathrm{mg} / \mathrm{kg}$, respectively. The bibliographic review reports a variability of results on the coconut composition, attributable to diverse factors, such as variety, agronomic management, edafoclimatological conditions of the production zone, state of maturity, among others (Siriphanich et al., 2011). Yalegama et al., (2013) reported for $\mathrm{CP}$ values of $\mathrm{Xw}$ : $41.7 \pm 0.5 \%$, fat $40.2 \pm 1.2 \%$, protein: $4.1 \pm 0.3$, sugar: $5.6 \pm 0.2 \%$, and raw fiber $3.5 \pm 0.1 \%$; while Appaiah et al., (2015) reported higher values of $\mathrm{Xw}(51.0 \pm 0.3 \%)$. Regarding calcium contents in $\mathrm{CW}$, the same variability occurs, reporting in unripe $(8.75 \pm 0.04 \mathrm{mg} / 100 \mathrm{~mL})$, ripe $(15.19 \pm 0.03 \mathrm{mg} / 100 \mathrm{~mL})$, and over-ripe states $(23.98 \pm 0.05 \mathrm{mg} / 100 \mathrm{~mL})$ (Thuan-Chew et al., (2014).

Tables 1,2 presents the distribution of the coconut parts and the $\mathrm{CP}$ and $\mathrm{CW}$ properties 
during storage. The ANOVA presented statistically significant differences $(p<0.05)$ in the $\mathrm{CW}$ and $\mathrm{CP}$ percentage ratios and the $\mathrm{CW}$ properties (Xw, ${ }^{\circ}$ Brix, density, IA, $\mathrm{pH}, \mu$ and $\left.b^{*}\right)$ with respect to the time factor; while there were no significant differences $(p>0.05)$ in the $\mathrm{CP}$ properties, or in the percentage ratio of the inner shell, the IP and in the CW a $\mathrm{a}_{\mathrm{w}}, \mathrm{L}^{*}$ and $\mathrm{a}^{*}$. The CW had a tendency to diminish the mass $(30.1 \rightarrow 15.4 \%)$, which has been observed during the physiological maturation during harvest by other authors and which continues during postharvest (Jackson et al., 2004; Terdwongworakul et al., 2009); while the CP and the peel tend to increase over time: $(47.1 \rightarrow 55.2 \%) \quad$ and $\quad(26.0 \rightarrow 33.8 \%)$, respectively. The $\mathrm{CP}$ and $\mathrm{CW}$ physiological phenomena are typical during maturation and senescence of this fruit, promoted by respiration, transpiration, and water absorption by the solid endosperm (Thuan-Chew et al., 2014; Siriphanich et al., 2011).

Table 1. Physical composition of CW and CP during storage

\begin{tabular}{|c|c|c|c|c|c|c|c|c|}
\hline $\begin{array}{c}\mathbf{T} \\
\text { (days) }\end{array}$ & $\begin{array}{l}\text { CW } \\
(\%)\end{array}$ & $\begin{array}{l}\text { CP } \\
(\%)\end{array}$ & $\begin{array}{c}\text { Inner shell } \\
(\%)\end{array}$ & & $\mathbf{L}^{*}$ & $a^{*}$ & $\mathbf{b}^{*}$ & $\begin{array}{c}\mu(\mathrm{cP}) \\
\text { Texture } \\
(\mathbf{N})\end{array}$ \\
\hline \multirow{2}{*}{15} & \multirow{2}{*}{$30.1 \pm 5.2 \mathrm{c}$} & \multirow{2}{*}{$47.1 \pm 3.1 \mathrm{a}$} & \multirow{2}{*}{$26.0 \pm 3.8 \mathrm{a}$} & $\mathrm{CW}$ & $51.0 \pm 1.5 \mathrm{c}$ & $0.3 \pm 1.0 \mathrm{a}$ & $-1.0 \pm 0.3 \mathrm{a}$ & $0.7 \pm 0.1 \mathrm{ab}$ \\
\hline & & & & $\mathrm{CP}$ & $71.8 \pm 4.3 b$ & $-1.1 \pm 0.2 \mathrm{a}$ & $3.1 \pm 0.8 \mathrm{ab}$ & $81.1 \pm 8.3 \mathrm{a}$ \\
\hline \multirow{2}{*}{22} & \multirow{2}{*}{$22.8 \pm 9.1 \mathrm{~b}$} & \multirow{2}{*}{$49.5 \pm 3.8 \mathrm{ab}$} & \multirow{2}{*}{$30.4 \pm 7.1 \mathrm{ab}$} & $\mathrm{CW}$ & $52.2 \pm 0.44 b c$ & $-1.08 \pm 0.0 \mathrm{~b}$ & $\begin{array}{c}- \\
0.02 \pm 0.06 \mathrm{~b}\end{array}$ & $0.7 \pm 0.1 \mathrm{a}$ \\
\hline & & & & $\mathrm{CP}$ & $72.7 \pm 10.6 b$ & $-0.8 \pm 0.5 \mathrm{ab}$ & $3.7 \pm 1.9 \mathrm{ab}$ & $75.7 \pm 8.5 a$ \\
\hline \multirow{2}{*}{29} & \multirow{2}{*}{$22.3+5.7 b$} & \multirow{2}{*}{$51.9 \pm 4.7 \mathrm{ab}$} & \multirow{2}{*}{$30.0 \pm 5.3 \mathrm{ab}$} & $\mathrm{CW}$ & $49.0 \pm 3.7 \mathrm{c}$ & $1.5 \pm 1.8 \mathrm{a}$ & $-0.9 \pm 0.2 \mathrm{a}$ & $0.7 \pm 0.1 \mathrm{ab}$ \\
\hline & & & & $\mathrm{CP}$ & $67.4 \pm 5.2 \mathrm{ab}$ & $-0.8 \pm 0.3 \mathrm{ab}$ & $3.7 \pm 1.3 \mathrm{ab}$ & $78.0 \pm 13.9 \mathrm{a}$ \\
\hline \multirow{2}{*}{36} & \multirow{2}{*}{$21.1 \pm 6.2 b c$} & \multirow{2}{*}{$52.9 \pm 8.9 \mathrm{bc}$} & \multirow{2}{*}{$29.5 \pm 7.1 \mathrm{ab}$} & $\mathrm{CW}$ & $50.9 \pm 3.0 \mathrm{c}$ & $0.6 \pm 1.0 \mathrm{a}$ & $-1.0 \pm 0.2 \mathrm{a}$ & $0.7 \pm 0.1 \mathrm{ab}$ \\
\hline & & & & $\mathrm{CP}$ & $67.5 \pm 10.9 \mathrm{ab}$ & $-1.2 \pm 0.2 \mathrm{a}$ & $2.4 \pm 1.5 \mathrm{a}$ & $71.2 \pm 6.3 \mathrm{a}$ \\
\hline \multirow{2}{*}{42} & \multirow{2}{*}{$15.9 \pm 6.6 \mathrm{ab}$} & \multirow{2}{*}{$53.6 \pm 2.4 \mathrm{ab}$} & \multirow{2}{*}{$31.0 \pm 4.5 \mathrm{ab}$} & $\mathrm{CW}$ & $50.7 \pm 2.0 \mathrm{c}$ & $-0.4 \pm 1.9 a$ & $-1.1 \pm 0.4 \mathrm{a}$ & $0.8 \pm 0.1 b c$ \\
\hline & & & & $\mathrm{CP}$ & $69.6 \pm 9.0 \mathrm{~b}$ & $-0.3 \pm 1.5 b$ & $4.2 \pm 1.9 \mathrm{ab}$ & $73.1 \pm 15.0 \mathrm{a}$ \\
\hline \multirow{2}{*}{50} & \multirow{2}{*}{$15.4 \pm 1.5 \mathrm{a}$} & \multirow{2}{*}{$55.2 \pm 3.6 \mathrm{~b}$} & \multirow{2}{*}{$33.8 \pm 7.4 b$} & $\mathrm{CW}$ & $50.8 \pm 1.2 \mathrm{c}$ & $2.4 \pm 2.8 \mathrm{a}$ & $-1.2 \pm 0.3 \mathrm{a}$ & $0.8 \pm 0.1 b c$ \\
\hline & & & & $\mathrm{CP}$ & $61.7 \pm 6.9 \mathrm{a}$ & $-0.8 \pm 0.6 \mathrm{ab}$ & $3.7 \pm 2.0 \mathrm{ab}$ & $73.5 \pm 19.8 \mathrm{a}$ \\
\hline
\end{tabular}

CW: coconut water; CP: coconut pulp; $\mu$ : viscosity; The values in the same column of the same variable, with the same letters indicate that there are no significant differences $(\mathrm{p}>0.05)$.

Table 2. Chemical composition of $\mathrm{CW}$ and $\mathrm{CP}$ during storage

\begin{tabular}{|c|c|c|c|c|c|c|c|}
\hline T (days) & & $\begin{array}{l}\mathbf{X w} \\
(\%)\end{array}$ & aw & ${ }^{\circ}$ Brix & $\begin{array}{c}\text { ÍP } \\
\left(\mathrm{meqH}_{2} \mathrm{O}_{2} /\right. \\
\mathrm{kg} \text { oil })\end{array}$ & $\begin{array}{c}\text { ÍA } \\
(\mathbf{p} / \mathbf{v})\end{array}$ & pH \\
\hline \multirow[t]{2}{*}{15} & $\mathrm{CW}$ & $96.1 \pm 0.8 \mathrm{c}$ & $0.981 \pm 0.007 \mathrm{~b}$ & $3.7 \pm 0.6 \mathrm{a}$ & \multirow{2}{*}{$0.7 \pm 0.3 \mathrm{a}$} & $0.04 \pm 0.01 \mathrm{a}$ & $\begin{array}{c}5.7 \pm 0.4 c \\
d\end{array}$ \\
\hline & $\mathrm{CP}$ & $50.4 \pm 5.2 b c$ & $0.978 \pm 0.005 \mathrm{a}$ & $6.4 \pm 3.0 \mathrm{bc}$ & & $0.51 \pm 0.24 \mathrm{a}$ & $6.1 \pm 0.2 b$ \\
\hline \multirow[t]{2}{*}{22} & $\mathrm{CW}$ & $95.9 \pm 0,4 \mathrm{c}$ & $0.974 \pm 0.011 \mathrm{ab}$ & $4.0 \pm 0.4 \mathrm{ab}$ & \multirow{2}{*}{$2.1 \pm 2.5 \mathrm{a}$} & $0.04 \pm 0.01 \mathrm{a}$ & $\begin{array}{c}6.0 \pm 0.3 \mathrm{c} \\
\mathrm{d}\end{array}$ \\
\hline & $\mathrm{CP}$ & $48.5 \pm 5.3 \mathrm{bc}$ & $0.978 \pm 0.005 a$ & $5.1 \pm 1.7 \mathrm{ab}$ & & $0.60 \pm 0.16 \mathrm{ab}$ & $6.0 \pm 0.3 b$ \\
\hline \multirow[t]{2}{*}{29} & $\mathrm{CW}$ & $95.9 \pm 1.0 \mathrm{c}$ & $0.952 \pm 0.076 \mathrm{a}$ & $4.1 \pm 1.0 \mathrm{ab}$ & \multirow{2}{*}{$2.3 \pm 2.0 \mathrm{a}$} & $0.07 \pm 0.02 \mathrm{a}$ & $6.2 \pm 0.2 \mathrm{a}$ \\
\hline & $\mathrm{CP}$ & $47.9 \pm 4.6 \mathrm{bc}$ & $0.979 \pm 0.003 \mathrm{a}$ & $4.8 \pm 1.1 \mathrm{ab}$ & & $0.66 \pm 0.11 \mathrm{ab}$ & $5.6 \pm 0.8 \mathrm{a}$ \\
\hline
\end{tabular}


Lucas Aguirre et al. /Carpathian Journal of Food Science and Technology 2019,11(3), 80-85

\begin{tabular}{|c|c|c|c|c|c|c|c|}
\hline 36 & $\mathrm{CW}$ & $95.1 \pm 1.2 \mathrm{~cd}$ & $0.971 \pm 0.012 \mathrm{ab}$ & $5.1 \pm 1.1 b c$ & \multirow{2}{*}{$2.8 \pm 2.4 \mathrm{a}$} & $0.08 \pm 0.01 \mathrm{a}$ & $5.5 \pm 0.6 b$ \\
\hline & $\mathrm{CP}$ & $51.2 \pm 6.7 \mathrm{c}$ & $0.979 \pm 0.007 \mathrm{a}$ & $4.0 \pm 1.9 \mathrm{a}$ & & $0.68 \pm 0.13 \mathrm{ab}$ & $6.0 \pm 0.2 b$ \\
\hline \multirow[t]{2}{*}{42} & $\mathrm{CW}$ & $94.0 \pm 1.6 \mathrm{abc}$ & $0.969 \pm 0.012 \mathrm{ab}$ & $5.8 \pm 1.6 \mathrm{~cd}$ & \multirow{2}{*}{$3.5 \pm 4.0 \mathrm{a}$} & $0.08 \pm 0.02 \mathrm{a}$ & $5.7 \pm 0.6 b$ \\
\hline & $\mathrm{CP}$ & $45.8 \pm 3.9 \mathrm{ab}$ & $0.976 \pm 0.005 a$ & $5.2 \pm 2.3 \mathrm{ab}$ & & $0.66 \pm 0.17 \mathrm{ab}$ & $6.0 \pm 0.2 b$ \\
\hline \multirow[t]{2}{*}{50} & $\mathrm{CW}$ & $93.5 \pm 1.5 \mathrm{ab}$ & $0.969 \pm 0.013 \mathrm{ab}$ & $7.1 \pm 1.8 \mathrm{~cd}$ & \multirow{2}{*}{$3.9 \pm 1.8 \mathrm{a}$} & $0.14 \pm 0.01 \mathrm{a}$ & $5.6 \pm 0.1 b$ \\
\hline & $\mathrm{CP}$ & $50.1 \pm 6.0 \mathrm{bc}$ & $0.978 \pm 0.005 a$ & $4.6 \pm 1.8 \mathrm{ab}$ & & $0.72 \pm 0.16 b c$ & $6.0 \pm 0.2 b$ \\
\hline
\end{tabular}

CW: coconut water; CP: coconut pulp; Xw: \% humidity; ÍP: peroxide index; ÍA; acidity index, expressed in expressed as malic acid for AC and as lauric acid for PC. The values in the same column of the same variable, with the same letters indicate that there are no significant differences $(\mathrm{p}>0.05$

The bibliographic review reports that on full maturity, changes in percentage distribution of coconut (Cocos nucifera L.) present many fluctuations: $\mathrm{CP}(28 \rightarrow 33 \% \mathrm{p} / \mathrm{p}), \mathrm{CW}(6 \rightarrow 25$ $\% \mathrm{p} / \mathrm{p})$, peel $(31 \rightarrow 54 \% \mathrm{p} / \mathrm{p})$ (Jayalekshmy et al., 1986; Siriphanich et al., 2011; Appaiah et al., 2015). The Xw of the CP had values between 51.2 and $45.8 \%$, with $\mathrm{CW}$ showing values of 96.1-92.5\%, corresponding in all cases to high values of $\mathrm{a}_{\mathrm{w}}(0.980-0.952)$, which makes these matrices perishable and favorable to microbial growth and degradation processes (Appaiah et al., 2015; Haseena et al., 2010). The soluble solids of the $\mathrm{CW}$ increase progressively throughout the storage time, which could be attributed to internal dehydration undergone by the fruit and it is coherent with the decrease previously mentioned of the percentage ratio of the $\mathrm{CW}$ and of the $\mathrm{Xw}$ of the $\mathrm{CW}(96.1 \pm 0.8$ $\rightarrow 93.5 \pm 1.5$ ).

With respect to the CW's $\mu$, it tends to increase mainly because of the higher content of soluble solids in the $\mathrm{CW}$ concentrated over time $(3.7 \pm 0.6 \rightarrow 7.1 \pm 1.8)$. The $\mathrm{CP}$ firmness $\left(\mathrm{F}_{\mathrm{CP}}\right)$ provided by the fiber content present and of rigid or hard nature (Yalegama et al., 2013; Raghavendra et al., 2009) behaved as a homogeneous group with high variability, fluctuating between $81.1 \pm 8.3$ and $73.5 \pm 19.8 \mathrm{~N}$. Some authors have reported CP softening during storage because of $\mathrm{CP}$ disintegration and deterioration due to fungal growth, where the most frequent found in the coconut peels are Aspergillus spp., Penicillium spp., Fusarium spp., and Curvulria spp. (Haseena et al., 2010; Luengwilai et al., 2014).
The IP displayed similar behavior during storage time $\left(0.74 \pm 0.3 \rightarrow 3.9 \pm 1.8 \mathrm{meqH}_{2} \mathrm{O}_{2} / \mathrm{kg}\right)$; it is a useful indicator of the degree of oxidation of lipids, fats, and oils that reduces stability and produces the formation of unpleasant taste that affect quality negatively during storage, as well as consumer acceptance due to the rancid odor (Hornero-Méndez et al., 2001). Some authors have defined the start of rancidity in coconut when IP reaches values of 35.5 meq $\mathrm{O}_{2}$ peroxide/kg oil (Waisundara et al., 2007), a value higher than the maximum reached for the $\mathrm{CP}+\mathrm{CW}$ mixture at $25{ }^{\circ} \mathrm{C}\left(1.6 \mathrm{meq}_{2} \mathrm{O}_{2} / \mathrm{kg}\right.$ oil $)$ (11.3 meq $\mathrm{O}_{2}$ peroxide/kg oil); however, at 29 days of storage a strong rancid odor became evident. Now then, changes in IP were low for $\mathrm{CP}$ and $\mathrm{CW}$; nevertheless, a tendency is noted to increased acidity and diminished $\mathrm{pH}$ over time, which revalidates the fermentation odors and rancidity of the product.

Regarding the color of the $\mathrm{CW}, \mathrm{L}^{*}$ varied from $51.0 \pm 1.5$ to $50.8 \pm 1.2$, showing a translucent liquid phase with a light brown tone and/or yellowing, emitting bad odor that could be attributable to the contraction and discoloration of the skin, the fall of the perianthus, and fungal attack in the soft perianthus region (Haseena et al., 2010); while chromaticities $\mathrm{a}^{*}$ and $\mathrm{b}^{*}$ had values close to zero in the chromatic plane $a^{*}, b^{*}$, indicating its achromaticity or placement in the zone of grey tones. The $\mathrm{CP}$ was bright white, where $\mathrm{L}^{*}$ varied between $71.8 \pm 4.3$ and $61.7 \pm 6.9$; while chromaticity $\mathrm{a}^{*}$ remained between $-1.1 \pm 0.2$ and $-0.8 \pm 0.6$, and lastly $b^{*}$ from $3.1 \pm 0.8$ to $3.7 \pm 2.0$, very similar behavior to that reported by Luengwilai et al., (2014), where no statistically 
significant differences were noted in variables $\mathrm{L}^{*} \mathrm{a}^{*}$, while $\mathrm{b}^{*}$ diminished 1.05 to -0.96 .

Up to 29 to 36 dah, coconut does not show appreciable organoleptic changes that demerit its quality, but as of this time (42 dah) deterioration symptoms were observed (in $\mathrm{CW}$ and $\mathrm{CP}$ ), like fermentation odors, fungal problems, softening and discoloration of the pulp, among others. This behavior coincides with that reported by Luengwilai et al., (2014), who worked with Macapuno coconut, where peeled ripe coconut was stored at 2,5 , and $30^{\circ} \mathrm{C}$ and its quality was evaluated after three days. During storage at $30{ }^{\circ} \mathrm{C}$, the fruit showed a 3day useful life. In contrast, with storage at 2 or 5 ${ }^{\circ} \mathrm{C}$ the storage life increased from three days to six weeks

\section{Conclusions}

The Enano Malayo coconut variety with acceptable quality for use as raw material in food processing must have a storage time below 29 dah. During this time, the physical-chemical and sensory characteristics of the products are within the acceptance limits; however, the fruit had high variability in $\mathrm{CP}$ and $\mathrm{CW}$ properties, which is due to the poor or almost null traceability available for this fruit.

\section{References}

AGRONET (2013). Red de Información y Comunicación Estratégica del Sector Agropecuario - AGRONET Colombia. Ministerio de Agricultura y Desarrollo Rural [on line].

http://www.agronet.gov.co/estadistica/Pagi nas/default.aspx> [cited 15 February 2017].

AOCW. (1990) Official methods of analysis of the Association of Official Analytical Chemists. 2 vols. $15^{\text {th }}$ ed. Washington, DC. Appaiah, P., Sunil, L., Prasanth Kumar. P.K., \& Gopala Krishna, A.G. (2015). Physicochemical characteristics and stability aspectsisperiof coconut water and kernel at different stages of maturity. Journal Food Science Technology, 52(8), 5196-5203.
Bae, E.K., \& Lee, S.J. (2008). Microencapsulation of avocado oil by spray drying using whey protein and maltodextrin. Journal of Microencapsulation, 25(8), 549560.

Cortés, M. (2004). Desarrollo de productos de manzana deshidratados enriquecidos con vitamina E. Universidad Politécnica de Valencia.

Cortés-Rodríguez, M., Guardiola, L. F., Pacheco, R. (2007). Aplicación de la ingeniería de matrices en la fortificación de mango (var. Tommy Atkins) con calcio. Revista Dyna, 74(153), 19-26.

Debmandal, M. and Mandal S. (2011). Coconut (Cocos nucifera L.: Arecaceae): In health promotion and disease prevention. Asian Pacific Journal of Tropical Medicine, 4(3), 241-247.

Haseena, M., Kasturi Bai., M.V., \& Padmanabhan, S. (2010). Post-harvest quality and shelf-life of tender coconut. Journal Food Science Technology, 47(6), 686-689.

Hornero-Méndez, D., Pérez-Gálvez, A. Mínguez-Mosquera, M.I. (2001). A Rapid Spectrophotometric Method for the Determination of Peroxide Value in Food Lipids with High Carotenoid Content. Journal of the American Oil Chemists' Society, 78(11), 1151-1155.

Jackson, J., Gordon, A., Wizzard, G., McCook, K., Rolle, R. (2004). Changes in chemical composition of coconut (Cocos nucifera) water during maturation of the fruit. Journal of the Science of Food and Agriculture, 84, 1049-1052.

Jayalekshmy, A., Arummaghan, C., Narayanan, S., Mathew, A.G. (1986). Changes in the chemical composition of coconut water during maturation. Journal Food Science Technology, 23, 203-207.

Luengwilai, K., Beckles, D.M., Pluemjit, O., Siriphanich, J. (2014). Postharvest quality and storage life of 'Makapuno' coconut (Cocos nucifera L.). Scientia Horticulturae, 175, 105-110. 
Mirhosseini, H., Ping Tan, C., Hamid, N.S.A., Yusof, S. (2008). Effect of Arabic gum, xanthan gum and orange oil contents on $\zeta$ potential, conductivity, stability, size index and $\mathrm{pH}$ of orange beverage emulsion. Colloids and Surfaces A: Physicochemical and Engineering Aspects, 315, 47-56.

NTC 5151 (2003). Alimento para animales. Determinación de los contenidos de calcio, cobre, hierro, magnesio, potasio, sodio y zinc. Método usado espectrometría de absorción atómica.

Prieto, W.H., Iguti, A.M., Nitz, M. (2011). Drying evaluation of green coconut pulp for obtaining a snack-like product. Procedia Food Science, 1, 1618 - 1627.

Raghavendra, S.N., Ramachandra-Swamy, S.R., Rastogi, N.K., Raghavarao, K.S.M.S., Kumar, S., Tharanathan, R.N. (2006). Grinding characteristics and hydration properties of coconut residue: A source of dietary fiber. Journal of Food Engineering, 72, 281-286.

Seow, C.C. and Gwee, C.N. (1997). Coconut milk: chemistry and technology. International Journal of Food Science and Technology, 32, 189-201.

Siriphanich, J., Saradhuldhat, P., Romphophak, T., Krisanapook, K., Pathaveerat, S., Tongchitpakdee, S. (2011). Coconut (Cocos nucifera L.). In: Yahia, E. (Ed.). Postharvest- Biology and Technology of Tropical and Subtropical Fruits. Vol 3: Cocona to Mango. Woodhead Publishing in Food Science Technology and Nutrition, Cambridge, UK. 8-33. doi:10.1533/9780857092885.

Terdwongworakul, A., Chaiyapong, S., Jarimopas, B., \& Meeklangsaen, W. (2009). Physical properties of fresh young Thai coconut for maturity sorting. Biosystem Engineering, 103, 208-216.

Thuan-Chew, T., Lai-Hoong, C., Rajeev. B., Gulam, R., Azhar, M.E. (2014). Composition, physicochemical properties and thermal inactivation kinetics of polyphenol oxidase and peroxidase from coconut (Cocos nucifera) water obtained from immature, mature and overly-mature coconut. Food Chemistry, 142, 121-128.

Waisundara, V. Y., Perera, C. O., Barlow, P. J. (2007). Effect of different pre-treatments of fresh coconut kernels on some of the quality attributes of the coconut milk extracted. Food Chemistry, 101, 771-777.

Yalegama, L.L.W.C., Karunaratne, D.N., Sivakanesan, R., Jayasekara, C. (2013). Chemical and functional properties of fiber concentrates obtained from by-products of coconut kernel. Food Chemistry, 141, 124130. 